\title{
Polyphenol content and pharmacological activities of Capsicum frutescens and $C$. chinense genotypes
}

\author{
ZULFIKAR DAMARALAM SAHID ${ }^{1}$, MUHAMAD SYUKUR ${ }^{2, \boldsymbol{v}}$, AWANG MAHARIJAYA ${ }^{2}$, \\ WARAS NURCHOLIS ${ }^{3}$ \\ ${ }^{1}$ Doctoral Program in Plant Breeding and Biotechnology, Department of Agronomy and Horticulture, Faculty of Agriculture, Institut Pertanian Bogor. \\ Jl. Meranti, IPB Dramaga Campus, Bogor 16680, West Java, Indonesia \\ ${ }^{2}$ Department of Agronomy and Horticulture, Faculty of Agriculture, Institut Pertanian Bogor. Jl. Meranti, IPB Dramaga Campus, Bogor 16680, \\ Indonesia. Tel. +62-251-629346 fax.+62-251-629352 `email: muhsyukur@apps.ipb.ac.id \\ ${ }^{3}$ Department of Biochemistry, Faculty of Mathematics and Natural Sciences, Institut Pertanian Bogor. J1. Agatis, IPB Dramaga Campus, Bogor 16680,
} Indonesia

Manuscript received: 24 July 2021. Revision accepted: 23 August 2021.

\begin{abstract}
Sahid ZD, Syukur M, Maharijaya A, Nurcholis W. 2021. Polyphenol content and pharmacological activities of Capsicum frutescens and C. chinense genotypes. Biodiversitas 22: 3838-3843. Chili is a horticultural crop with potential as a functional food crop. This is because chili has beneficial biochemical parameters such as antioxidants, phenolics, flavonoids, and $\alpha$-glucosidase inhibitors. This study evaluated the biochemical parameters in twelve genotypes of two chili species (Capsicum frutescens and Capsicum chinense). Information from this research can be used as a reference in chili plant breeding activities which are directed as functional food plants. The method of measuring biochemical parameters using an ELISA reader with a modified method. Samples were measured with a microplate and repeated three times. The results that emerged from the ELISA reader were then converted with Microsoft Excel and analyzed using the R program. The results showed that the Capsicum chinense species (Habanero Fransisca) had the highest $\alpha-$ glucosidase inhibitory activity $(52.52 \%)$ compared to other genotypes of the Capsicum frutescens species. The highest TPC (19.42), TFC (2.51), and antioxidant FRAP (117.27) were shown by the pure line genotype F8 285290-290-2-2-4-4-1. The biochemical content of the chili genotypes tested was divided into three major groups. This grouping is not affected based on the species used. The correlation between antioxidants using the FRAP method with TFC $(0.69)$ and TPC $(0.83)$ is positive and significantly different. In conclusion, information on biochemical content can be used as a basis for developing genotypes, especially for the purposes of plant breeding activities in the future.
\end{abstract}

Keywords: Antioxidant, chili, $\alpha$-glucosidase, phenolic, flavonoid

\section{INTRODUCTION}

Diabetes is a condition in which there is a buildup of blood sugar levels due to absolute or relative insulin deficiency (Blair 2016). The World Health Organization (WHO) reports that by 2030, diabetes is estimated to be the highest cause of death in the world. Chemical treatment of diabetes causes adverse side effects (Liu and Ma 2017). Therefore, alternative treatments are used through natural chemical compounds found in plants (Kumar et al. 2011). Higher plants produce secondary metabolites called polyphenols that play an important role in plant physiological processes and have potential health compounds for humans (Daglia 2012).

Some plants have natural chemical compounds called $\alpha$-glucosidase inhibitors which function to inhibit the absorption of sugar in the blood (Yin et al. 2014). One of the plants that have the potential to be developed to have $\alpha$ glucosidase inhibitor compounds is chili (Watcharachaisoponsiri et al. 2016). Chili is a horticultural plant that is reported to have several beneficial chemical compounds (Mougiou et al. 2021). The main chemical compound in chili is capsaicin which functions to control the spiciness of chilies (Sahid et al. 2020a). In addition to capsaicin, chili peppers contain various biochemical antioxidants, phenolics, flavonoids, and $\alpha$-glucosidase inhibitors (Zhang et al. 2021).

Information on the biochemical content of antioxidants, phenolics, flavonoids, and $\alpha$-glucosidase inhibitors can be used in plant breeding activities to assemble new highyielding varieties. The function of plant antioxidants is to regulate enzymes related to reactive oxygen species and defend cells from free radicals (Ishihara et al. 2018). Synthetic antioxidants from butylated hydroxyanisole and butylated hydroxytoluene are carcinogenic (Devi et al. 2019). Therefore, the discovery of natural antioxidants with non-toxic compounds is important to do.

The aim of this study is to identify biochemical parameters such as phenolic contents, flavonoid contents, antioxidant, and $\alpha$-glucosidase inhibitory activities in several chili genotypes of two species (Capsicum frutescens and Capsicum chinense). In addition, our hypothesis is that there is a relationship between the biochemical characters of the chili genotype and species. The results of this study can provide scientific information on chili plant breeding activities in the future. 


\section{MATERIALS AND METHODS}

\section{Study area and genetic material}

Randomized complete block design single factor namely the genotype of chili plants used in this study. The materials used in this study were 12 genotypes of chili collected by the Plant Breeding Education Laboratory, IPB University, consisting of 10 genotypes of Capsicum frutescens species and 2 genotypes of Capsicum chinense (Table 1). The biochemical content test was repeated 3 times.

The initial stage of this research was the cultivation of various genotypes of chili in the greenhouse housing IPB Alam Sinar Sari. Experimental activities begin with seeding activities. Fertilization is done after the seedlings are 2 weeks old after sowing using $\mathrm{AB}$ Mix fertilizer. Planting is done after the chili seedlings are 30 days old after sowing into pots with a diameter of $30 \mathrm{~cm}$. Maintenance activities are carried out, namely watering in the morning and evening, fertilizing is done once a week using AB Mix fertilizer specifically for chili. Pesticide spraying was carried out every 2 weeks using insecticides with active ingredients Prefonofos and Abamectin $(2 \mathrm{~mL} \mathrm{~L}$ $\left.{ }^{1}\right)$. Harvesting is done when the chili has reached a red color and then used as material for biochemical analysis.

\section{Biochemical analysis}

\section{Sample preparation}

The sample that will be used in the analysis of the biochemical content is chili. The red chilies were then measured wet weight and dried using an oven at $40^{\circ} \mathrm{C}$ for 2 x 24 hours. The dried chili was weighed as a measurement of dry weight and crushed to become chili powder. Then 3 grams of chili powder was taken and dissolved in $60 \mathrm{~mL}$ of $80 \%$ ethanol (ratio 1:20). The extract was incubated in a dark condition for $3 \times 24$ hours, then filtered and transferred to a glass bottle until the volume reaches 50 $\mathrm{mL}$. The extract was stored in the refrigerator for $2 \times 24$ hours before being used for biochemical analysis.

\section{Total phenolic content}

Measurement of total phenolic content using the modified Malik and Ahmad (2015) method. $20 \mu \mathrm{L}$ of sample extract and $100 \mu \mathrm{L}$ of Folin-Ciocalteu reagent $50 \%$ (in distilled water) in a microplate and allowed to stand for 5 minutes. $80 \mu \mathrm{L} \mathrm{Na}_{2} \mathrm{CO}_{3} 7.5 \%$ (w/v in distilled water) was reacted with the sample. Then, the mixture was incubated for 120 minutes in the dark condition. The sample was measured using an ELISA reader at a wavelength of 750 $\mathrm{nm}$. The standard used is $500 \mathrm{ppm}$ gallic acid. The final unit of analysis was expressed in mg GAE (Gallic Acid Equivalent) per gram extract.

\section{Total flavonoid content}

Measurement of total flavonoid content using the method of Nisa et al. (2017) modified. $10 \mu \mathrm{L}$ of sample extract was mixed with $60 \mu \mathrm{L}$ of methanol, $10 \mu \mathrm{L}$ of $10 \%$ $\mathrm{AlCl}_{3}$ (in methanol), $10 \mu \mathrm{L}$ of $1 \mathrm{M} \mathrm{CH} \mathrm{CH}_{3} \mathrm{COOK}$ (in methanol), and $110 \mu \mathrm{L}$ of distilled water into the microplate. Then, the mixture was homogenized and incubated for 30 minutes in the dark condition. The sample was measured using an ELISA reader at a wavelength of $415 \mathrm{~nm}$. The standard used is Quercetin with concentration levels of $25 \mathrm{ppm}$ until $200 \mathrm{ppm}$. The final unit of analysis was expressed as mg QE (Quercetin Equivalent)/g extract. Calculation of flavonoid content is calculated using the formula:

$$
y=a+b x
$$

Where:

y: absorbance

a: intercept

b: slope liniar curve

$\mathrm{x}$ : concentrate (ppm)

r: relation coefficient

\section{Antioxidant DPPH method}

The measurement of antioxidants DPPH method refers to the research of Maesaroh et al. (2018) modified. $100 \mu \mathrm{L}$ of sample extract and $100 \mu \mathrm{L}$ of positive control solution (Trolox) that had been prepared were put into a microplate. Then, each solution was added $100 \mu \mathrm{L}$ of $125 \mu \mathrm{M}$ DPPH (2,2-diphenyl-1-picrylhydrazyl) in ethanol. Then, the mixture was homogenized and incubated for 30 minutes in a dark condition. The sample was measured using an ELISA reader at a wavelength of $517 \mathrm{~nm}$. The standard used is Trolox with a concentration level of 20-800 $\mu \mathrm{M}$. The final unit of analysis was expressed as $\mu$ mol TE (Trolox Equivalent)/g extract.

\section{Antioxidant FRAP method}

Measurement of antioxidants FRAP method refers to the modified study of Loodu and Rupasinghe (2019). $10 \mu \mathrm{L}$ of sample extract was added to $300 \mu \mathrm{L}$ of FRAP (Ferric Reducing Antioxidant Power) reagent and put into a microplate. Then the mixture was homogenized and incubated for 30 minutes at $37^{\circ} \mathrm{C}$ in a dark condition. FRAP reagent was prepared by mixing acetate buffer $\mathrm{pH}$ 3.6; $1 \mathrm{mM}$ TPTZ in $40 \mathrm{mM} \mathrm{HCl}$; and $20 \mathrm{mM} \mathrm{FeCl}_{3}$ in distilled water with a volume ratio of 10:1:1. The sample was measured using an ELISA reader at a wavelength of $595 \mathrm{~nm}$. The standard used is Trolox with a concentration level of $20-800 \mu \mathrm{M}$. The final unit of analysis was expressed as mol TE (Trolox Equivalent)/g extract.

Table 1. Twelve genotype Capsicum frutescens and C. chinense

\begin{tabular}{ll}
\hline \multicolumn{1}{c}{ Genotypes } & \multicolumn{1}{c}{ Species } \\
\hline PULAIPILA & Capsicum frutescens \\
BONITA & Capsicum frutescens \\
CIBEUREUM & Capsicum frutescens \\
F8 285290-123-6-15-4-1-1 & Capsicum frutescens \\
F8 285290-9-2-1-2-2-2 & Capsicum frutescens \\
F8 285290-290-2-2-4-4-1 & Capsicum frutescens \\
F8 285290-290-9-2-1-1-1-2 & Capsicum frutescens \\
F8 285290-290-9-1-4-2-1 & Capsicum frutescens \\
F9 285290-6-10-1-1-1-1-1 & Capsicum frutescens \\
F9 321290-111-252-10-5-4-1-1 & Capsicum frutescens \\
PEACH CHUPETINHO & Capsicum chinense \\
HABANERO FRANSISCA & Capsicum chinense \\
\hline
\end{tabular}


Inhibitor $\alpha$-glucosidase activity

Measurement of -glucosidase inhibitor refers to the study of Wibisono et al. (2019) modified. A total of $10 \mu \mathrm{L}$ of sample solution was added with $50 \mu \mathrm{L}$ of $0.1 \mathrm{M}$ phosphate buffer with a $\mathrm{pH}$ of $7,25 \mu \mathrm{L} \alpha$-glucosidase 0.04 $\mathrm{U} \mathrm{mL}^{-1}$ and $25 \mu \mathrm{L}$ of p-nitrophenyl- $\alpha-D$ glucopyranoside $0.5 \mathrm{mM}$ were inserted into a microplate. A control buffer was used without the addition of enzymes. Then it was incubated for 30 minutes at $37^{\circ} \mathrm{C}$ and stopped using $100 \mu \mathrm{L}$ $\mathrm{Na}_{2} \mathrm{CO}_{3} \quad 0.2$ M. The solution was measured using an ELISA reader at a wavelength of $410 \mathrm{~nm}$. The activity of the inhibitor $\alpha$-glucosidase was calculated using the formula:

Inhibitor Activity: [Absorbance $_{\text {Control }}-$ Absorbance $_{\text {Sample }}$ / Absorbance Control $_{\text {x }}$ 100\%

\section{Data analysis}

Analysis of the variance of biochemical content using the SAS 9.0 program. Differences in genotypes were tested using the $\mathrm{F}$ test with a significance level of $5 \%$. If there is a significant difference, then proceed with the DMRT further test at 5\% level. Cluster analysis and the Pearson correlation test were carried out using the $\mathrm{R}$ Studio program with Performance Analytics packages (Peterson et al. 2014).

\section{RESULTS AND DISCUSSION}

The result of ANOVA test showed in Table 2. The mean square of the tested genotype showed a significant effect on all observed variables. In line with Sahid (2020a) showed that genotype differences resulted in observed differences in biochemical content as well. The replicates in the ANOVA test did not show a significant difference, thus indicating the stability of the biochemical content tested in this study. The value of the coefficient of variance in this study is between $8.47 \%-11.11 \%$. The smaller the value of the coefficient of variance $(20 \%<)$ means that the degree of authenticity and reliability will be higher so that the validity of the conclusions generated is also getting better (Döring and Reckling 2018). (Canchola et al. 2017) also states that the Coefficient of Variance indicates the degree of accuracy and the reliability of the conclusion of an experiment.

The mean genotype values based on biochemical content are described in Table 3. The pure line genotype F8 285290-290-2-2-4-4-1 has the highest TPC (19.42), TFC (2.51), and the highest antioxidant FRAP (117.27) compared with all tested genotypes. This genotype is a species of chili Capsicum frutescens. The highest $\alpha$ glucosidase inhibitory activity was shown by Capsicum chinense (Habanero Fransisca) with an inhibitory power of $52.52 \%$ compared to other genotypes. Watcharachaisoponsiri et al. (2016) reported that $\alpha$-glucosidase inhibitory activity in Capsicum frutescens was in the range of $22.6 \%-48.80 \%$. In line with this study that Capsicum Frutescens has $\alpha$ glucosidase inhibitory activity up to $50.01 \%$ indicated by genotype F8 285290-290-9-2-1-1-1-2. The highest antioxidant from the DPPH method was found in the Peach Chupetinho genotype of the Capsicum chinense species. This result in line with research (Olatunji and Afolayan 2019) which showed that high phenolic and flavonoid compounds were found in chili species Capsicum frutescens.

Table 2. ANOVA of biochemical content on chili

\begin{tabular}{|c|c|c|c|c|c|}
\hline \multirow{2}{*}{ Sources } & \multicolumn{5}{|c|}{ Mean square } \\
\hline & TPC & TFC & DPPH & FRAP & AGI \\
\hline Genotype & $24.86 * *$ & $0.68 * *$ & $7.97 * *$ & $2334.45 * *$ & $125.68 * *$ \\
\hline Replication & $0.38 \mathrm{~ns}$ & $0.01 \mathrm{~ns}$ & $0.76 \mathrm{~ns}$ & $29.08 \mathrm{~ns}$ & $58.16 \mathrm{~ns}$ \\
\hline Error & 1.63 & 0.02 & 1.11 & 46.25 & 15.82 \\
\hline Coefficient of variance $(\%)$ & 8.47 & 11.11 & 8.54 & 9.81 & 9.01 \\
\hline
\end{tabular}

Note: **: very significantly at level $\alpha$ 1\%; ns: non-significant; TPC: Total Phenolic Content, TFC: Total Flavonoid Content, DPPH: Antioxidant DPPH Method, FRAP: Antioxidant FRAP Method, AGI: $\alpha$-glucosidase inhibitory activity.

Table 3. Mean value of biochemical content on chili genotypes

\begin{tabular}{|c|c|c|c|c|c|}
\hline Genotype & TPC & TFC & DPPH & FRAP & AGI \\
\hline PULAIPILA & $11.92^{\mathrm{fg}}$ & $0.82^{\text {gh }}$ & $13.63^{\mathrm{ab}}$ & $39.49^{f}$ & $46.90^{\mathrm{a}}$ \\
\hline BONITA & $11.80^{\mathrm{fg}}$ & $0.89^{\text {fgh }}$ & $12.71^{b c}$ & $39.72^{\mathrm{f}}$ & $48.08^{\mathrm{a}}$ \\
\hline CIBEUREUM & $17.83^{\mathrm{abc}}$ & $1.40^{\mathrm{b}}$ & $11.78^{\mathrm{bcd}}$ & $61.25^{\mathrm{e}}$ & $47.08^{\mathrm{a}}$ \\
\hline F8 285290-123-6-15-4-1-1 & $13.35^{\mathrm{ef}}$ & $1.04^{\operatorname{defg}}$ & $12.16^{\mathrm{bc}}$ & $70.97^{\mathrm{de}}$ & $45.84^{\mathrm{a}}$ \\
\hline F8 285290-9-2-1-2-2-2 & $17.04^{\mathrm{bcd}}$ & $1.21^{\text {bcde }}$ & $9.95^{\mathrm{de}}$ & $71.44^{\mathrm{de}}$ & $37.54^{\mathrm{b}}$ \\
\hline F8 285290-290-2-2-4-4-1 & $19.42^{\mathrm{a}}$ & $2.51^{\mathrm{a}}$ & $11.10^{\text {cde }}$ & $117.27^{\mathrm{a}}$ & $32.46^{\mathrm{b}}$ \\
\hline F8 285290-290-9-2-1-1-1-2 & $14.81^{\mathrm{de}}$ & $1.08^{\text {cdef }}$ & $12.29^{\mathrm{bc}}$ & $62.87^{\mathrm{e}}$ & $50.01^{\mathrm{a}}$ \\
\hline F8 285290-290-9-1-4-2-1 & $18.54^{\mathrm{ab}}$ & $1.27^{\mathrm{bcd}}$ & $13.31^{\mathrm{ab}}$ & $89.03^{\mathrm{b}}$ & $35.78^{\mathrm{b}}$ \\
\hline F9 $285290-6-10-1-1-1-1-1$ & $15.49^{\text {cde }}$ & $0.97^{\mathrm{efg}}$ & $9.61^{\mathrm{e}}$ & $76.76^{\mathrm{cd}}$ & $47.08^{\mathrm{a}}$ \\
\hline F9 $321290-111-252-10-5-4-1-1$ & $15.96^{\mathrm{cd}}$ & $0.85^{\text {fgh }}$ & $12.04^{\mathrm{bc}}$ & $98.52^{\mathrm{b}}$ & $48.93^{\mathrm{a}}$ \\
\hline PEACH CHUPETINHO & $10.17^{\mathrm{g}}$ & $0.70^{\mathrm{h}}$ & $14.73^{\mathrm{a}}$ & $16.81^{\mathrm{g}}$ & $37.81^{\mathrm{b}}$ \\
\hline HABANERO FRANSISCA & $14.85^{\text {ed }}$ & $1.32^{\mathrm{bc}}$ & $14.71^{\mathrm{a}}$ & $87.41^{\mathrm{bc}}$ & $52.52^{\mathrm{a}}$ \\
\hline
\end{tabular}

Note: Numbers followed by the same letter in the same column were not significantly different according to DMRT 5\% level; TPC: Total Phenolic Content; TFC: Total Flavonoid Content; DPPH: Antioxidant DPPH Method; FRAP: Antioxidant FRAP Method; AGI: $\alpha-$ glucosidase inhibitory activity. 
The genotypes that had the value of the antioxidant analysis results from the FRAP and DPPH methods showed differences between species. The highest antioxidant in the FRAP method was shown in the genotype of the Capsicum frutescens species, while the highest antioxidant in the DPPH method was shown in the genotype of the Capsicum chinense species. The different results according to (Sethi et al. 2020) were caused by the principle of the antioxidant method used. The FRAP (Ferric Reducing Antioxidant Power) method relies on the extract's ability to reduce $\mathrm{Fe}^{3+}$ to $\mathrm{Fe}^{2+}$. While the DPPH method (2,2dipenyl-1picrylhydrazyl) has the principle of free radical scavenging (Svečnjak et al. 2020). In this study, although different, the trend found is still the same, namely the genotype that has a high-test result value in the FRAP method will also be high in the DPPH method. Although it is not the highest, it is still included in the high class.

Information on the biochemical content tested can be used as a basis for selecting parents in plant breeding activities. Sahid et al. (2020b) stated that chili has biochemical compounds that can be utilized in the assembly of new varieties that are directed as functional food products. Capsicum chinense is known as a chili species that has the highest spiciness in the world (Jeeatid et al. 2018). The results of this study also showed that this species has a high content of $\alpha$-glucosidase inhibitors compared to Capsicum frutescens species.
Figure 1 shows the correlations between the observed biochemical variables (TPC, TFC, DPPH, FRAP, and $\alpha-$ glucosidase inhibitors). The $\alpha$-glucosidase inhibitors were positively correlated with DPPH but negatively correlated with TPC, TFC, and FRAP. Positive correlations and significantly different were shown between FRAP and TFC $\left(\mathrm{p}<0.05 ; \mathrm{r}^{2}\right.$ value 0.69$)$, FRAP and TPC $\left(\mathrm{p}<0.01 ; \mathrm{r}^{2}\right.$ value $0.83)$ and TFC and TPC ( $<<0.01 ; \mathrm{r}^{2}$ value 0.74$)$. Calvindi et al (2020) also report that FRAP and TPC were positively correlated and significantly different. The negative correlation and significantly different $\left(\mathrm{p}<0.1, \mathrm{r}^{2}\right.$ value 0.52) were shown by TPC and DPPH. Othman et al. (2014) in their research results also show the same results compared with these studies. The correlation between antioxidants with different methods (DPPH and FRAP) was negative $\left(\mathrm{r}^{2}\right.$ value -0.40$)$. In addition, the antioxidant DPPH also negatively correlated with TFC $\left(r^{2}\right.$ value -0.29$)$.

The relationship between the observed biochemical compounds and the used genotype is shown in Figure 2. The observed genotypes and biochemical characters were divided into three major groups. The group of one biochemical character consisted of TPC, TFC and FRAP. Groups two and three of biochemical characters were $\alpha$ glucosidase inhibitors and DPPH. The results show that the observed biochemical characters have no effect on the type of species. The color in the image indicates the intensity of the biochemical content. The brighter the displayed color (yellow), the higher the biochemical content it has.

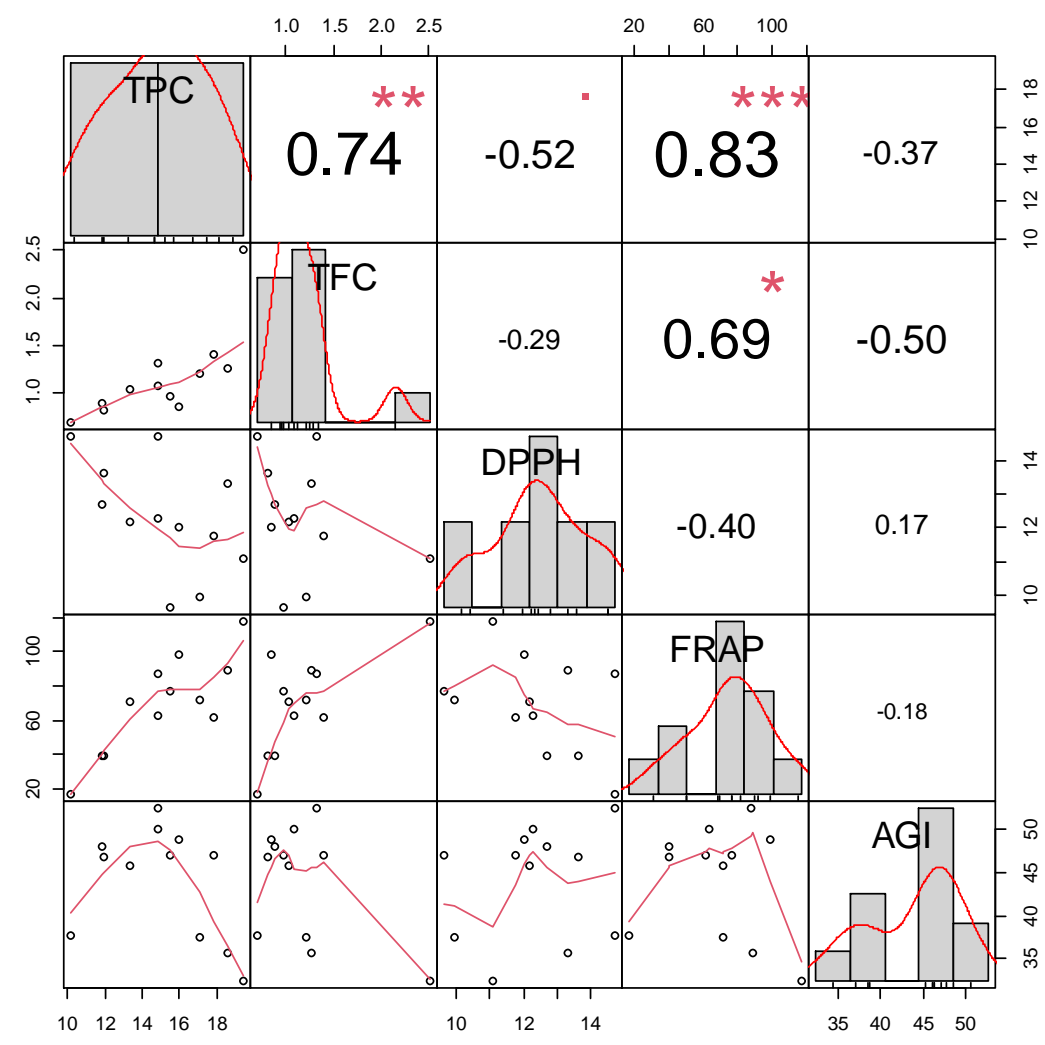

Figure 1. Correlation of Total Phenolic Content (TPC), Total Flavonoid Content (TFC), Antioxidant DPPH, Antioxidant FRAP and $\alpha$ glucosidase inhibitory activity (AGI) on chili genotype 


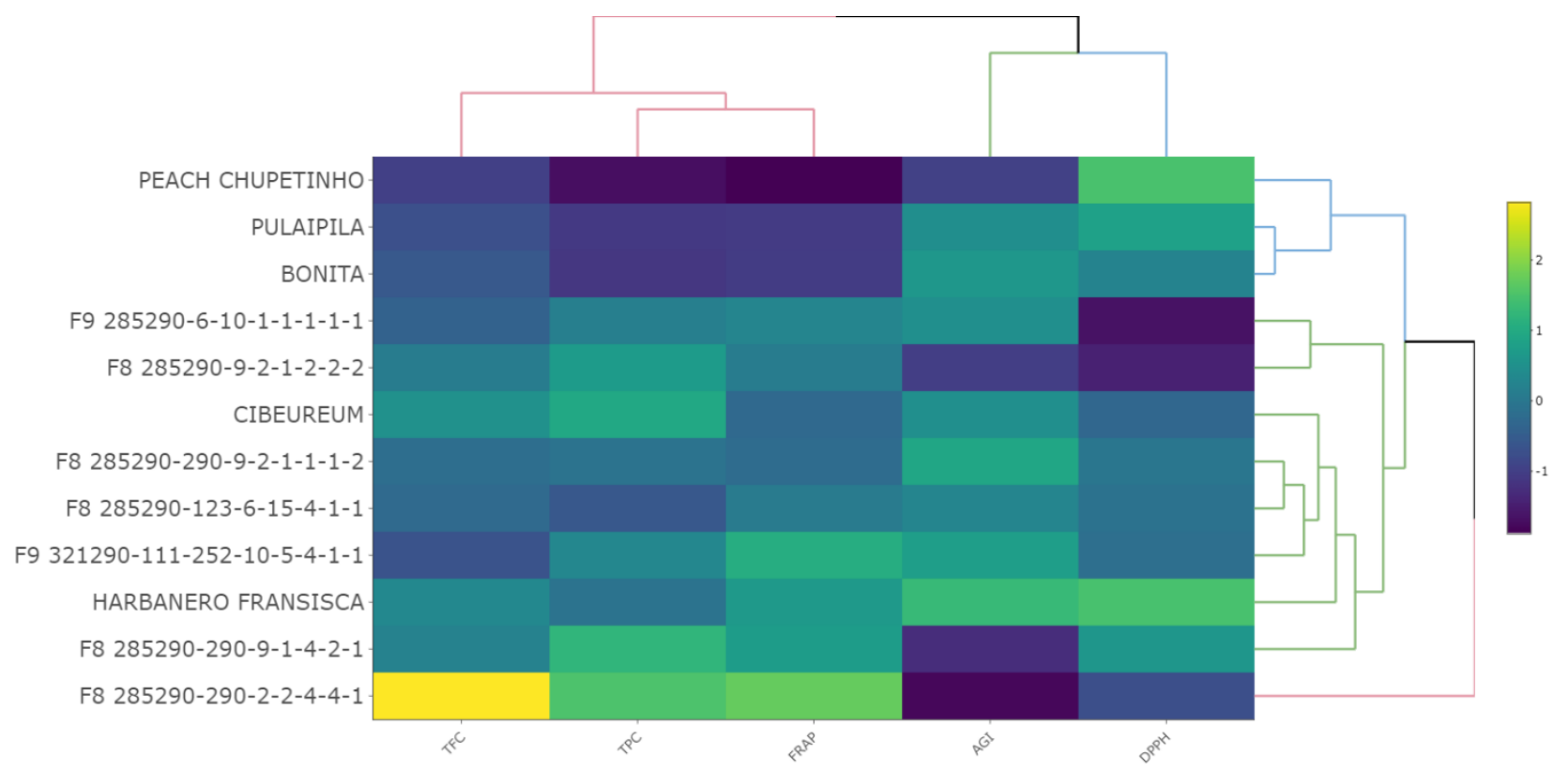

Figure 2. Cluster analysis of Total Phenolic Content (TPC), Total Flavonoid Content (TFC), Antioxidant DPPH, Antioxidant FRAP and $\alpha$-glucosidase inhibitory activity (AGI) on chili genotypes

The genotypes used were divided into 2 species, namely Capsicum frutescens and Capsicum chinense. The cluster analysis carried out resulted in three major groups in the genotype. The first group consisted of Peach Chupetinho (Capsicum chinense), Pulaipila, and Bonita (Capsicum frutescens). Group two consisted of Habanero Fransisca (Capsicum chinense), Cibereum, F8 285290-290-9-1-4-2-1, F9 285290-6-10-1-1-1-1-1, F8 285290-9- 2-1-2-2-2, F8 285290-290-9-2-1-1-1-2, F8 285290-123-6-15-4-1-1 and F9 321290-111-252-10- 5-4-1-1 (Capsicum frutescens). The third group is F8 285290-290-2-2-4-4-1.

In conclusion, the result demonstrated that biochemical characters of chili are influenced by different genotypes and species. The highest $\alpha$-glucosidase inhibitory activity was shown by the Capsicum chinense species (Habanero Fransisca) with an inhibitory power of $52.52 \%$. The pure lines genotype F8 285290-290-2-2-4-4-1 had the highest total phenolic content, total flavonoid content, and FRAP antioxidant activity compared to all tested genotypes. The highest DPPH antioxidant was shown by both genotypes of Capsicum chinense (Peach Chupetinho and Habanero Fransisca). Positive significant correlation results were shown by TPC-FRAP, TFC-FRAP, and TFC-TPC. While a significant negative correlation is shown by DPPH-TPC.

\section{ACKNOWLEDGEMENTS}

The authors would like to thank the Ministry of Research, Technology and Higher Education of the Republic of Indonesia for funding this research through the Applied Research of National Higher Education in 2020 and 2021 with Muhamad Syukur as the principal researcher.

\section{REFERENCES}

Blair M. 2016. Diabetes mellitus review. Urol Nurs 36: 27-36.

Calvindi J, Syukur M, Nurcholis W. 2020. Investigation of biochemical characters and antioxidant properties of different winged bean (Psophocarpus tetragonolobus) genotypes grown in Indonesia. Biodiversitas 21 (6): 2420-2424. DOI: 10.13057/biodiv/d210612.

Canchola JA, Tang S, Hemyari P, Paxinos E, Marins E. 2017. Correct use of percent coefficient of variation $(\% \mathrm{CV})$ formula for log-transformed data. MOJ Proteomics Bioinform 6 (4): $00200 . \quad$ DOI: 10.15406/mojpb.2017.06.00200.

Daglia M. 2012. Polyphenols as antimicrobial agents. Curr Opin Biotechnol 23 (2): 174-181. DOI: 10.1016/j.copbio.2011.08.007.

Devi J, Sanwal SK, Koley TK, Mishra GP, Karmakar P, Singh PM, Singh B. 2019. Variations in the total phenolics and antioxidant activities among garden pea (Pisum sativum L.) genotypes differing for maturity duration, seed and flower traits and their association with the yield. Sci Hortic (Amsterdam) 244: 141-150. DOI: 10.1016/j.scienta.2018.09.048.

Döring TF, Reckling M. 2018. Detecting global trends of cereal yield stability by adjusting the coefficient of variation. Eur J Agron 99: 3036. DOI: 10.1016/j.eja.2018.06.007.

Ishihara J, Umesawa M, Okada C, Kokubo Y, Iso H. 2018. Relationship between vegetables and fruits (antioxidant vitamins, minerals, and fiber) intake and risk of cardiovascular disease. In: Sawyer D, Vasan R (eds.). Encyclopedia of Cardiovascular Research and Medicine. 1st ed. Elsevier, Amsterdam.

Jeeatid N, Suriharn B, Techawongstien S, Chanthai S, Bosland PW, Suchila T. 2018. Evaluation of the effect of genotype-by-environment interaction on capsaicinoid production in hot pepper hybrids (Capsicum chinense Jacq.) under controlled environment. Scientia Horticulturae 235: 334-339. DOI: 10.1016/j.scienta.2018.03.022.

Kumar V, Prakash O, Kumar S, Narwal S. 2011. $\alpha$-glucosidase inhibitors from plants: A natural approach to treat diabetes. Pharmacogn 5: 1929. DOI: 10.4103/0973-7847.79096.

Liu Z, Ma S. 2017. Recent advances in synthetic $\alpha$-glucosidase inhibitors. Med Chem 12: 819-829. DOI: 10.1002/cmdc.201700216.

Maesaroh K, Kurnia D, Anshori JA. 2018. Perbandingan metode uji aktivitas antioksidan DPPH, FRAP dan FIC terhadap asam askorbat, asam galat dan kuerseti. Chimica et Natura Acta 6 (2): 93-100. DOI: 10.24198/cna.v6.n2.19049. [Indonesian] 
Malik A, Ahmad AR. 2015. Determination of phenolic and flavonoid contents of ethanolic extract of kanunang leaves (Cordia myxa L.). Int J Pharm Technol Res 7 (2): 243-246.

Mougiou N, Trikka F, Michailidou S, Pantoura M, Argiriou A. 2021. Molecular and biochemical characterization of the Greek pepper (Capsicum annuum) cultivars "Florinis" and "Karatzova". Polish J Food Nutr Sci 71 (1): 89-96. DOI: 10.31883/PJFNS/133690

Nisa K, Nurhayati S, Apriyana W, Indrianingsih AW. 2017. Investigation of total phenolic and flavonoid contents, and evaluation of antimicrobial and antioxidant activities from Baeckea frutescens extracts. IOP Conf Series: Earth and Environmental Science. DOI: 10.1088/1755-1315/101/1/0120022.

Olatunji TL, Afolayan AJ. 2019. Comparative quantitative study on phytochemical contents and antioxidant activities of Capsicum annuum L. and Capsicum frutescens L. Sci World J 2019: 4705140. DOI: $10.1155 / 2019 / 4705140$

Othman A, Mukhtar NJ, Ismail NS, Chang SK. 2014. Phenolics, flavonoids content and antioxidant activities of 4 Malaysian herbal plants. Int Food Res J 21 (2): 759-766.

Peterson BG, Carl P, Boudt K, Bennett R, Ulrich J, Zivot E. 2014 Performance analytics: Econometric tools for performance and risk analysis. R Package Version 1 (3541): 107.

Sahid ZD, Syukur M, Maharijaya A. 2020a. Diversity of capsaicin content, quantitative, and yield components in chili (Capsicum annuиm L.) genotypes and their F1 hybrid. Biodiversitas 21: 22512257. DOI: $10.13057 /$ biodiv/d210555.

Sahid ZD, Syukur M, Maharijaya A. 2020b. Combining ability and heterotic effects of chili pepper (Capsicum annиum L.) genotypes for yield components and capsaicin content. SABRAO J Breeding and Genetics 52 (4): 390-401.

Sethi S, Joshi A, Arora B, Bhowmik A, Sharma RR, Kumar P. 2020. Significance of FRAP, DPPH, and CUPRAC assays for antioxidant activity determination in apple fruit extracts. Eur Food Res Technol 246: 591-598. DOI: 10.1007/s00217-020-03432-Z

Svečnjak L, Marijanović Z, Okińczyc P, Kuś PM, Jerković I. 2020. Mediterranean propolis from the Adriatic Sea islands as a source of natural antioxidants: Comprehensive chemical biodiversity determined by GC-MS, FTIR-ATR, UHPLC-DAD-QqTOF-MS, DPPH and FRAP Assay. Antioxidants 9 (4): 337. DOI: 10.3390/antiox9040337.

Watcharachaisoponsiri T, Sornchan P, Charoenkiatkul S, Suttisansanee U. 2016. The $\alpha$-glucosidase and $\alpha$-amylase inhibitory activity from different chili pepper extracts. Int Food Res J 23 (4): 1439-1445.

Wibisono K, Aisyah SI, Suhesti S, Nurcholis W. 2019. Optimization of total flavonoids extraction and $\alpha$-glucosidase inhibitory activity from Plectranthus amboinicus (Lour.) Spreng. leaves using the simplexcentroid design. Molekul 14 (2): 84-91.

Yin Z, Zhang W, Feng F, Zhang Y, Kang W. 2014. $\alpha$-Glucosidase inhibitors isolated from medicinal plants. Food Sci Hum Wellness 3: 136-174. DOI: 10.1016/j.fshw.2014.11.003.

Zhang D, Sun X, Battino M, Wei X, Shi J, Zhao L, Liu S, Xiao J, Shi B, Zou X. 2021. A comparative overview on chili pepper (Capsicum genus) and Sichuan pepper (Zanthoxylum genus): from pungent spices to pharma foods. Trends Food Sci Technol DOI: 10.1016/j.tifs.2021.03.004. 